
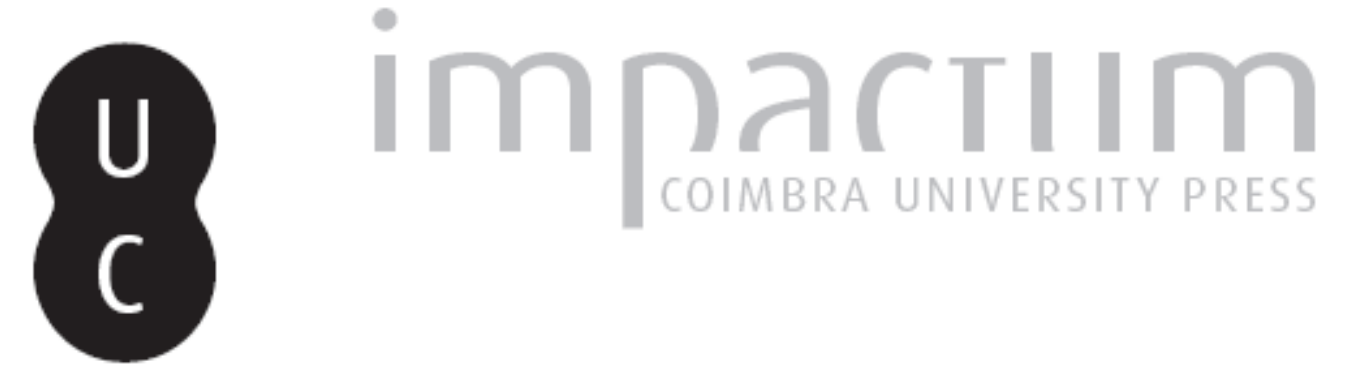

Thinking about war in ancient Mesopotamia: a prophetic discourse of legitimacy

Autor(es): $\quad$ Caramelo, Francisco

Publicado por: Centro de História da Universidade de Lisboa

URL persistente:

URI:http://hdl.handle.net/10316.2/23829

DOI:

DOI:http://dx.doi.org/10.14195/0871-9527_18_3

Accessed : $\quad$ 26-Apr-2023 08:15:08

A navegação consulta e descarregamento dos títulos inseridos nas Bibliotecas Digitais UC Digitalis, UC Pombalina e UC Impactum, pressupõem a aceitação plena e sem reservas dos Termos e Condições de Uso destas Bibliotecas Digitais, disponíveis em https://digitalis.uc.pt/pt-pt/termos.

Conforme exposto nos referidos Termos e Condições de Uso, o descarregamento de títulos de acesso restrito requer uma licença válida de autorização devendo o utilizador aceder ao(s) documento(s) a partir de um endereço de IP da instituição detentora da supramencionada licença.

Ao utilizador é apenas permitido o descarregamento para uso pessoal, pelo que o emprego do(s) título(s) descarregado(s) para outro fim, designadamente comercial, carece de autorização do respetivo autor ou editor da obra.

Na medida em que todas as obras da UC Digitalis se encontram protegidas pelo Código do Direito de Autor e Direitos Conexos e demais legislação aplicável, toda a cópia, parcial ou total, deste documento, nos casos em que é legalmente admitida, deverá conter ou fazer-se acompanhar por este aviso. 

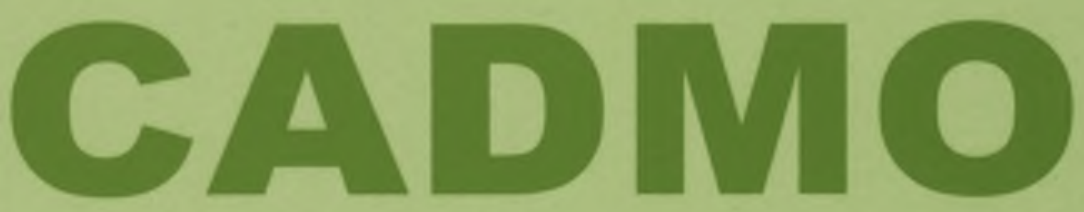

Revista de História Antiga

\author{
Centro de História \\ da Universidade de Lisboa
}

18

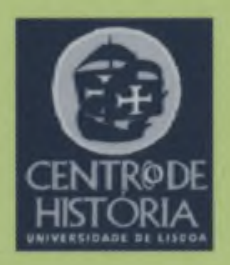

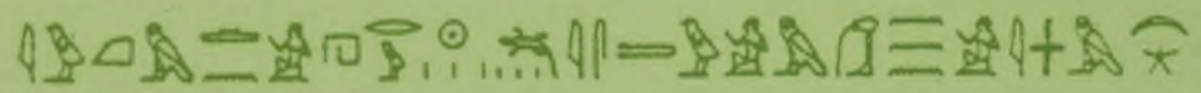

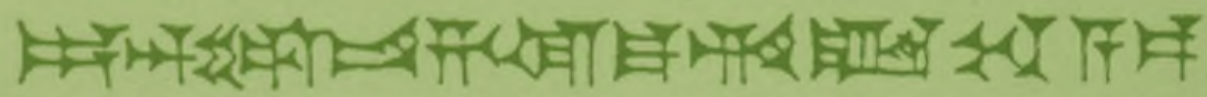

MHNIN AEI $\Delta$ E $\Theta E A ~ \Pi H \Lambda H I A \triangle E \Omega$ 


\title{
THINKING ABOUT WAR IN ANCIENT MESOPOTAMIA: A PROPHETIC DISCOURSE OF LEGITIMACY
}

\author{
FRANCISCO CARAMELO \\ Universidade Nova de Lisboa \\ F.Caramelo@netcabo.pt
}

\section{Resumo}

A guerra é uma das temáticas mais fortes na literatura de índole apologética e propagandística na Mesopotâmia. Principalmente na literatura analística assíria, encontramos uma fraseologia e uma linguagem que se apoia na metáfora, na hipérbole e no mito para sustentar uma ideologia que legitima o poder real, justificando as suas ambições. Esse discurso ganha contornos teológicos e morais, procurando definir a acção do rei como uma missão em nome dos deuses e da ordem que estes sustentam. Propomo-nos aqui analisar essa linguagem, identificando as suas linhas retóricas fundamentais.

Palavras-chave: Guerra; Ideologia; Realeza; Poder.

\section{Résumé}

La guerre est un sujet très important dans la littérature apologétique et propagandistique en Mésopotamie. On trouve dans les annales des rois assyriens une phraséologie et un langage où la métaphore, l'hyperbole et les références au mythe sont fréquentes. C'est un langage qui supporte une idéologie de légitimation du pouvoir. Ce discours, avec une dimension théologique et moral, essaye de définir l'action du roi comme une mission au nom des dieux et de l'ordre. On va essayer d'analyser ce langage et d'identifier ses lignes rhétoriques fondamentales.

Mots-clés: Guerre; Idéologie; Royauté; Pouvoir. 
Understanding war, its discourse, narrativity and ideology in ancient Mesopotamia implies the general comprehension of power and its relationship with the gods. Literary and iconographic sources express abundantly this idiosyncrasy placing the king at the core of this bond between heaven and earth. That is also the case of the literary sources we have used here: annals and royal inscriptions from Assurbanipal's reign (668-630 B.C.). These texts are obviously apologetic and propagandistic and reflect the ideological and political nature of the assyrian sovereign, his legitimacy and also his world mission. An example of this rhetoric may be read at the annals of Assurbanipal. The king displays his most significant royal titles on a formulaic expression which is commonly repeated through these texts and other sources as well:

I, Assurbanipal, the great king, the mighty king, king of the universe, king of Assyria, king of the four quarters (... $)^{(1)}$.

With a typical autobiographic style, the king asserts his status and role, not only as an assyrian sovereign but also as an universal monarch. The formula "king of the four quarters", for example, means the worldliness of his power. In fact, this set of titles, being diachronic and transversal in Mesopotamia and not specific of this period, comprehends different meanings. Sometimes, like during Assurbanipal's reign, political context appears to be close to this rhetoric of worldliness but most of the times there is a huge gap between this assertion and reality. These formulas reflect the expected political ambition and are intrinsically ideological. But saying that these formulas proclaim the recurrent political ambition and expectations of Mesopotamian kings is not enough; in fact, the king acts in the name of the gods and this idea explains his political and military action as a mission. Royal power is an instrument of gods used to establish order in the world. Therefore, the king is invested on this mission to accomplish god's will.

The concept of mission is based upon the belief that the king is chosen by gods to exercise power.

By order of the great gods, whose names I called upon, extolling their glory, who commanded that I should exercise sovereignty, assigned me the task of adorning their sanctuaries, assailed my opponents on my behalf, slew my enemies, the valiant hero, beloved of Assur and Ishtar, scion of royalty, am I(2).

Gods choose the king in order to exercise sovereignty over the country and the world. This election is explained by love and affection they feel for their chosen one. The divine's countenance is neither 
merely rhetoric nor limited to the formal act of election. Gods operate actively with the king, supporting him and participating as allies or on his behalf on wars against their enemies.

In conclusion, we would like to stress three ideas which in fact are structural and articulated on the political thought:

1) legitimacy comes from the gods and derives from divine election;

2) because of this election, the king becomes god's favourite, being placed above men and acquiring a special nature which makes him close to gods although not divine;

3) the acquired nature and his legitimacy uphold the mission which the king must accomplish in the name of gods.

The king's role and his political status are undoubtedly subordinated to divine's will and exist within the purpose of keeping worldly order. This ideological elaboration implies the existence of a legitimate order and the king has a central role on that process. Once power is conceptually envisaged as something that was originally created, and later preserved and legitimated by gods, the king as its interpreter is entirely subordinated to divine will ad arbitrium. In that sense, the enemy is perceived as an emanation of an external entity which opposes and acts against a legitimate order. The enemy does not act exclusively or merely against the king; he becomes eschatological once the concrete enemy is the circumstantial and objective manifestation of a structural and more permanent opposition.

In that sense, order is never definitive and final and is persistently attacked by external powers. This otherness is perceived as acting conceptually against a moral order and not only against the circumstantial king. The sovereign, as part of this legitimate and moral order, is engaged on the effort of struggling against others in order to defend his realm or even to expand legitimately his dominions.

When the enemy, subdued to Assyria, decides to rebel against assyrian order, the attitude is envisaged as an immoral act. The uprising is perceived as ungrateful behaviour towards the magnanimous assyrian king and the personal attitude of local leaders as an unfaithful behaviour:

(...) these kings, as many as I had reinstated, sinned against the oath sworn to me, did not heed the curse of the great gods, forgot the good I had done them, and their hearts planned evil.(3)

The assyrian king had reinstated the local monarchs and trusted them but his trust was betrayed by those vassal kings. Their behaviour 
is interpreted as a sin, as an evil act against moral order which is represented by the assyrian king, god's favourite. This legal and moral transgression is based upon oblivion. Those kings neglect and forget the favours and the grace they have received from the merciful assyrian king and that's the origin of their evil intentions.

Assyrian king reveals a benevolence contrasting with the sinful and evil behaviour of the rebels. That benevolence is inspired by the great gods. Likewise, the malevolence of the enemy has its origin and is affiliated to Tiamat:

(...) offspring of Tiamat, image of [the devil] ${ }^{(4)}$, disregarded the oath by the gods not to do evil against, not to overstep the border of my land $(\ldots)^{(5)}$.

The seditious king is the image of evil and the offspring of Tiamat, the primeval monster-goddess, defeated by Marduk who afterwards used her body to create and organize the world as we know it. This is an explicit assertion that there is an organic and ideological correlation between rebels and Tiamat, who opposed divine order. On the other hand, worldly order and victory against seditious enemies also correspond also to the recurrent renewal of the primeval triumph over Tiamat and her army of evil creatures.

The assyrian king was ideally the head of an universal monarchy. $\mathrm{He}$ was the legitimate sovereign of a kingdom extending "from the Upper Sea to the Lower Sea(6)" and the "kings of the rising and the setting sun $^{(7)}$ brought their tribute ${ }^{(8)}$ » to him. The diversity of this empire is well illustrated here:

The tongues of the lands of the rising and setting sun, which Assur had put into my hands $(\ldots)^{(9)}$.

The linguistic diversity was an effective argument on the process of showing clearly how worldly and universal was assyrian monarchy. The god Assur, the supreme deity among the Assyrians, was the ultimate responsible for that universal mission and it was to him that the assyrian king was accountable.

War is perceived on this context as a trial, a test between the two opponents, the assyrian king and his adversary. God is simultaneously the judge and his favourite's ally. This ideological topos is very common in literary sources:

Assur, Bêl, Nabû, Nergal, the great gods, my lords, decreed a righteous judgement in my favour and against Ummanigash ${ }^{(10)}$. 
Both opponents are identified. The conflict will be decided through a judgement but it is assumed beforehand that the assyrian king will be delivered and his enemy shall be condemned.

The partiality is due to the love gods feel for their favourite but also to moral superiority displayed by the king's character and nature. The assyrian king is always pious and faithful, trusting on his own gods, praying and assuming his humbleness, and asking for help once in distress. In contrast with the attitude of the assyrian king, the enemy trusts in his own strength and disregards god's will:

(...) because he did not heed the word of Assur, the god who created me, but trusted in his own strength, and hardened his heart ${ }^{(11)}$.

Enemy's unfaithfulness is ascribed to his ungratefulness towards the assyrian king their patron:

(...) these kings, as many as I had reinstated, sinned against the oath sworn to me, did not heed the curse of the great gods, forgot the good I had done them, and their hearts planned evil. They plotted insurrection, following their own counsel $(\ldots)^{(12)}$.

The negligence regarding the gods and the ingratitude towards their patron, their suzerain, are concomitant aspects of an impious and immoral behaviour, which is mostly human, contrasting with the assyrian king whose attitudes and deeds almost sanctify him.

In face of affliction, brought by sudden war, the assyrian king exposes his humility and even his vulnerability, although only before god. He prays and god answers:

Ishtar heard my distressful sighs. "Do not fear," she said, and put trust into my heart. "Because of thy hands which thou hast raised in prayer, and thy eyes which were filled with tears, I have had mercy upon thee."(13)

The formula "do not fear" is common in prophetic oracles. Pray and oracle should be understood as a logical scheme of petition and answer and this dialogic relationship is also structural on the theoretic definition of power. Communication with god overcomes accidental Ioneliness of power and despair.

Gods encourage their favourite and promise their help. Nevertheless, they go beyond the words of encouragement; they participate actively in war, determining it, commanding it, and actually fighting for their favourite one. They act as allies of the assyrian king changing 
the course of war even when enemies are numerous. This idea of an universal conspiracy against the assyrian king, who acts alone but having his gods as allies, is also a topos on this literary genre.

Ishtar of Arbela, one of the most important deities on the assyrian pantheon, was known by her warlike behaviour totally committed with king's protection. Revealing herself to a seer, through a prophetic dream, strongly armed with bow and a sharp sword, she addresses the king:

Thou shalt remain here, where the abode of Nabû is. Eat food, drink wine, provide music, honor my divinity, until I go and carry out this work and cause thee to attain unto thy heart's desire. Thy face shall not grow pale, thy feet shall not be weary, thy strength shall not fail in the midst of battle ${ }^{(14)}$.

The goddess alone will fight the enemy and the king will remain at home, safe and enjoying life and its pleasures. There is no reason to be apprehensive or fearful. She endeavours to calm her favourite one, dealing with him on a very protective and sometimes maternal manner.

Although these literary sources (annals) also narrate the personal participation of the king in battlefield (and we are aware that some of the assyrian kings did really involve themselves in hostile actions), the existence of these narratives does not always mean that kings had indeed participated actively. These narratives follow an ideological program where the assyrian king plays a central role, being the protagonist:

Countless warriors of his I slew, with the sword I cut down his mighty fighters (...). I struck down the people living therein. I smashed their gods, and pacified the divine heart of the lord of lords ${ }^{(15)}$.

In fact, we are aware that the autobiographic style of the narrative does not correspond to a real involvement of the assyrian king but the message was essentially that he should be envisaged as an hero acting in the name of the gods and trying to appease them.

Enemy's rebellion and treason provokes a dramatic and enraged reaction from the assyrian gods and the offended king. Let's look at an example:

At the command of Assur, Sin, Shamash, Adad, Bêl, Nabû, Ishtar of Nineveh, the queen of Kidmuri, Ishtar of Arbela, Urta, Nergal, Nusku (...), like the onset of a terrible hurricane I overwhelmed Elam in its 
entirety. I cut off the head of Teumman, their king, - the haughty one, who plotted evil. Countless of his warriors I slew. Alive, with my hands, I seized his fighters. With their corpses I filled the plain (...). Their blood I let run down the Ulai; its water I dyed red like wool(16).

The relationship between Assyria and Elam, on the southwest of Iran, was never easy. Teumman, the seditious king, wanted to create instability on the south of Mesopotamia. His actions were perceived as an evil conspiracy against the legitimate order and as an offence to the gods, patrons of the assyrian king. At the command of the great gods, the assyrian king became the avenger and punisher. The narrative builds an hyperbolic discourse regarding the assyrian action and war. The use of literary images and metaphors illustrate the terror and the overwhelming reaction of the ruthless and unmerciful assyrian king fighting, with god's help, the evil enemy.

Other images of cruelty occur through these narratives:

Those of them who fled before the murderous iron dagger, famine, want and flaming fire, and found a refuge, - the net of the great gods, my lords, which cannot be eluded, brought them low. Not one escaped; not a sinner slipped through my hands (...). Their dismembered bodies I fed to the dogs, swine, wolves, and eagles, to the birds of heaven and the fish of the deep ${ }^{(17)}$.

The narrative is characterized by rhetoric of violence, which purpose was king's glorification displaying his intimacy with god and the uselessness of hostile actions against him. There can not be doubts that gods are behind his favourite and violence is nothing more than the effective exhibition of divine intolerance regarding the sinner and enemy.

Enemies in battlefield are perceived as lambs slaughtered ${ }^{(18)}$ by the assyrian king and his troops. The principal gods march ahead, as a first line of attack, slaughtering the opponents ${ }^{(19)}$. Assyrian attack is intended to be devastator, ravaging the enemies and their cities, and is described as such. The rhetoric formula «l captured, I destroyed, I devastated, I burned with fire ${ }^{20)}$ is often repeated through these literary sources, almost synthesizing the extraordinary belligerent action of the assyrian king. Always on an autobiographic narrative style, he stresses his unmerciful and ruthless reaction to the sinful behaviour of the enemy:

(...) their hearts, I tore out $(\ldots)$ their lips I cut off $(\ldots)$ their tongues I tore out, their flesh I fed to the vultures ${ }^{(21)}$. 
The pitiless attitude of the assyrian king is reactive and morally justified by the serious ignominiousness of the enemy's actions and also because the assyrian king has the divine mandate to defend and to expand the legitimate order.

The exhibition of violence was intended to stress the assyrian king's superiority and his closeness to assyrian gods. Teumman's head was displayed in Nineveh, the assyrian capital:

The severed head of Teumman I displayed conspicuously in front of the gate inside Niniveh, that the severed head of Teumman, king of Elam, might show the people the might of Assur and Ishtar. ${ }^{(22)}$

Ideologically and rhetorically, the elamite monarch became before Nineveh, its people and its king, a pictogram of evil, sin and rebellion against gods and legitimate order. This message was also meant to be understood by Assyrians in their own realm.

The narratives also mention the divine weapons and how fearful they were to the terrified enemies. The "powerful weapons of Assur and Ishtar" and also the "splendour of Assur and Ishtar»(23) were impressive and spread the panic among foes:

The terrible brilliance of Assur and Ishtar, my lords; and the fear of my majesty, overwhelmed them ${ }^{(24)}$.

Ishtar, the assyrian goddess, is often depicted, on literary and iconographic scenes, strongly armed, prepared to battle, eager to protect and defend her beloved one.

The net is a powerful divine weapon. Gods use it to catch enemies like birds:

Those of them who fled before the murderous iron dagger, famine, want and flaming fire, and found a refuge, - the net of the great gods, my lords, which cannot be eluded, brought them low. Not one escaped; not a sinner slipped through my hands, of those whom they had counted for my hands. ${ }^{(25)}$

The net was associated with gods and was a weapon no one could avoid. Gods used it like hunters and launched it to catch the enemies.

In sight of the unavoidable and invincible power of gods and their protégé, the enemy had only two possibilities: either accept the assyrian yoke or suffer the humiliation and the cruelty of defeat. The 
subdued enemy will be fiercely treated and will be displayed in front of everyone:

The people dwelling therein, who had not come forth and had not greeted my majesty, I slew. Their heads I cut off. I pierced the lips and took them to Assyria as a spectacle for the people of my land. ${ }^{(26)}$

Victory is undoubtedly an attribute of the assyrian king and rewards his righteous behaviour. It is genetically associated with kingship and it should be clear to everyone that no one could oppose its power and succeed.

Enemy's submission is often illustrated by kissing king's feet ${ }^{(27)}$ and total humiliation is the price that must be paid by him:

(...) they came in their nakedness, crawling on their bellies, and laid hold of my feet (...). ${ }^{(28)}$

Nakedness and crawling are the most effective and dramatic pictures of a humiliating attitude. Servitude was the consequence and the corollary of submission which is also illustrated by symbolic acts. The gods made the assyrian king "stand upon the neck»(29) of his foes or put a "dog chain» ${ }^{(30)}$ upon his enemy. These literary metaphors, structured on an ideological and rhetorical frame, served the purpose of establishing clearly and antithetically the conflict between order and disorder.

Is this moral and ideological discourse compatible with what we usually define as holy war? There is no doubt that this political and ideological discourse it is also a religious discourse, nevertheless, religion is used in ancient Mesopotamia to build and forge national identity and we never observe proselytism or an intention of converting others. Religious thought and discourse explains order and legitimates power. War does not exist in order to impose religious ideas or a foreign god and his cult. Likewise it does not forbid local cults or gods. Religious thought and discourse perceives war as a way of expanding order, the political order legitimated by assyrian gods. However, when the enemy, or the other, recognizes assyrian superiority that includes the assumption that at least politically, assyrian gods are also superior.

Our literary sources put on view an obvious unilateralist thought on these matters, displaying an idiosyncratic view regarding political and social order. This unilateralist thought is quite manifest when Assyrians, while not denying the existence of other gods and their 
cult, elucidate that enemy's defeat was accepted and explained by them as a transgression of the oath they have sworn:

The people of Arabia asked questions, the one of the other, saying: "Why is it that such evil has befallen Arabia?" And answered, saying: "Because we did not keep the solemn oaths sworn to Assur; because we have sinned against the kindness shown us by Assurbanipal, the king beloved of Enlil's heart."(31)

That is the same argumentation we have observed above but this time used by others. The disloyalty and the infidelity regarding the assyrian gods and their king are the causa belli. Even the enemy's gods corroborate the punishing war and the assyrian victory:

Because of the evil deeds which he did to my house, his gods have been angry with him, they have left him, they have sought other lands. ${ }^{(32)}$

This unilateralist thought assumes that even the enemy's gods legitimate an universal order and are part of it.

The concept of holy war is not appropriate on this context. There is nothing similar to crusades or proselytism. However, gods decide wars and participate actively on them. We should consider the concept of divine war. War is the context where gods display their power, judge king's performance and fight for a universal order. In that sense, war is righteous and legitimate. Power, given by gods, exists to establish and preserve order and presupposes structural communication between them and their protégé. War is, in this context, seen as part of a theocentric thought being power in itself the instrument of gods, legitimated by them, to establish order or re-establish it whenever universal order is disrupted ${ }^{(33)}$.

\section{Notes}

(1) Daniel LUCKENBILL, Ancient Records of Assyria and Babylonia Volume II Historical Records of Assyria from Sargon to the End, New York: Greenwood Press, Publishers, 1968, p.321 = ARAB II, p.321 (Cylinder of Rassam, col. X, II. 51-120).

(2) $A R A B$ II, p.292 (Cylinder of Rassam, col. I, II. 1-51).

(3) ARAB II, p.294 (Cylinder of Rassam, col. I, I.52 - col. II, I.27).

(4) That's not devil like in christian interpretation but the enemy as an image or expression of evil. In mesopotamian thought, we can not find the existence of an absolute evil or a 
dualistic partition of the world between good and evil; instead of that, the enemy and some entities, some human and others supernatural, operate as manifestations and perpetrators of disorder against the moral and unilateral order.

(5) ARAB II, p.384 (KK 120, b + $144+3298+3265)$.

(6) This was a formula meaning referring to a territory extending from the Mediterranean to the Persian Gulf.

(7) From the East to the West.

(8) ARAB II, p.345 (Cylinder D, col. V, II. 1-17).

(9) ARAB II, p.346 (Cylinder E).

(10) ARAB II, p.336 (Cylinder B, col. VI, I.10 - col. VII, I. 58).

(11) ARAB II, p.298 (Cylinder of Rassam, col. II, II.49-125).

(12) ARAB II, p.294 (Cylinder of Rassam, col. I, I.52 - col. II, I.27).

(13) ARAB II, p.332 (Cylinder B, col. IV, I.84 - col. VI, I.9).

(14) Idem, ibidem.

(15) ARAB II, p.308 (Cylinder of Rassam, col. V, I.63 - col. VII, I.81).

(16) ARAB II, p.300 (Cylinder of Rassam, col. III, II.27-127).

(17) ARAB II, p.304 (Cylinder of Rassam, col. III, I.128-col. IV, I09).

(18) ARAB II, p.300 (Cylinder of Rassam, col. III, II.27-127).

(19) ARAB II, p.303 (Cylinder of Rassam, col. III, I.128-col. IV, 109).

(20) ARAB II, p.307 (Cylinder of Rassam, col. IV, I.110-col. V, I.62).

(21) It's not a text from the annals. It's $\mathrm{K} 4453$ (ARAB I, p. 404).

(22) ARAB II, p.335 (Cylinder B, col. VI, I.10-col. VII, I.58).

(23) ARAB II, p.313 (Cylinder of Rassam, col. V, I.63-col. VII, I.81).

(24) ARAB II, p.305 (Cylinder of Rassam, col. IV, I.110-col. V, I.62).

(25) ARAB II, p.304 (Cylinder of Rassam, col. III, I.128-col. IV, 109).

(26) $A R A B$ II, p.306 (Cylinder of Rassam, col. IV, I.110-col. V, I.62).

(27) $A R A B$ II, p.295 (Cylinder of Rassam, col. II, II.28-48).

(28) $A R A B$ II, p.361 (K 2825).

(29) $A R A B$ II, p.306 (Cylinder of Rassam, col. IV, I.110-col. V, I.62).

(30) $A R A B$ II, p.315 (Cylinder of Rassam, col. VII, I.82-col. X, I.50).

(31) $A R A B$ II, p.318 (Cylinder of Rassam, col. VII, I.82-col. X, I.50).

(32) ARAB II, p.403 (K $2647+\mathrm{Rm}, 2,99)$.

(33) This paper was delivered at the European Social Science History Conference, which took place at the Faculty of Letters - University of Lisbon $\left(26^{\text {th }}\right.$ February $-1^{\text {st }}$ March 2008). I'm grateful to Dr. Miguel Conde who helped me revising it. 


\section{Bibliography}

ALON, I., GRUenWALD, I., SingeR, I. (eds.), Concepts of the Other in Near Eastern Religions, Leiden, E.J. Brill, 1994.

BORGER, R., Beiträge zum Inschriftenwerk Assurbanipals, Wiesbaden, Harrassowitz Verlag, 1996.

CARAMELO, F., A linguagem profética na Mesopotâmia (Mari e Assíria), Cascais, Patrimonia, 2002.

KUHRT, A., The Ancient Near East c. 3000-330 BC, London-New York, Routledge, 1998.

LUCKENBILL, D., Ancient Records of Assyria and Babylonia Volume II Historical Records of Assyria from Sargon to the End, New York, Greenwood Press, Publishers, 1968.

ODED, B., War, peace and empire. Justifications for war in Assyrian royal inscriptions, Wiesbaden, Dr. Ludwig Reichert Verlag, 1992.

PARPOLA, S., WATANABE, K. (eds.), Neo-assyrian Treaties and Loyalty Oaths, Helsinki, Helsinki University Press, 1988.

WESTENHOLZ, J. G., Legends of the Kings of Akkade: the texts, Winona Lake, Eisenbrauns, 1997. 